\title{
'They Bleed from Long-Healed Scars': A Nietzschean Psychological Perspective on the Literature of Inherited Colonial Trauma in New Zealand
}

See to it that no one takes you captive through hollow and deceptive philosophy, which depends on human tradition and the elemental spiritual forces of this world.

Colossians 2:8.

How do we account for the ideological orientation of so much of the literature produced by academics in New Zealand over the past three decades dealing with the state of the country's indigenous population? Specifically, how do we explain the near uniformity in these works when addressing themes associated with the ongoing crises and trauma of colonisation that are purportedly bearing down on Māori? The self-evident response would be to take this literature at face value - observing the overtly Marxist architecture both of its arguments and the conceptualisation of the salient issues, ${ }^{1}$ and unquestioningly assume that colonisation is indeed a current as well as historical phenomenon in New Zealand; that it imposes crises and trauma on the country's indigenous population; that its causes are systemic; that the coloniser's racism is the axiomatic governing principle upholding this process; ${ }^{2}$ that there is a 
culturally, politically and ethnically monolithic entity known as 'Māori'; and that Māori agency is so limited that the process appears destined to be perpetually ruinous. This is an extraordinary series of contingent relationships, and obviously exposes itself to serious historical, political, sociological, and cultural critiques.

However, while the current paucity of such critiques is in itself problematic when making any claims that assert the robustness and conceptual integrity of these works (which is compounded by the worrying stagnation of theoretical evolution and critiques within the corpus of this literature), there is a specific psychological dimension overarching these works and some of the rationales imbued within them which can provide an ontological framework for evaluating their claims, and indeed their entire validity. This philosophical dimension hinges on the notion of ressentiment, as deployed by Friedrich Nietzsche in embryonic form in Birth of Tragedy (1872) and Human All Too Human (1878), and more systematically and comprehensively in Beyond Good and Evil (1886) and Genealogy of Morals (1887), and which was also referred to in Ecce Homo (1888). It is principally in Genealogy of Morals, though, where the essence of ressentiment is encapsulated. As Nietzsche succinctly put it:

every sufferer instinctively seeks a cause for his suffering, more exactly, an agent; still more specifically a guilty agent who is susceptible to suffering - in short, some living thing upon which he can on some pretext or other, vent his affects, actually or in effigy ... This ... constitutes the actual physiological cause of ressentiment, vengefulness, and the like: a desire to deaden pain by means of affects ... to deaden, by means of a more violent emotion of any kind, a tormenting, secret pain that is becoming unendurable, and to drive it out of consciousness at least for the moment: for that one requires an affect, as savage an affect as possible, and, in order to excite that, any pretext at all. ${ }^{3}$ 
This work applies some of the tenets of ressentiment, in the way Nietzsche constructed the notion, to a loose body of literature dealing with the present state of Māori in New Zealand. This literature is bound by its particular perspectives on colonisation, which one writer in the group defines as 'a historical trauma event', asserting that:

'[h]istorical trauma caused by colonisation is the root cause of intergenerational issues.... Research tells us that traumatic events like that impose themselves on an entire people and have major implications for the following generations who are trying to adapt to the trauma that their parents, their grandparents, and their great grandparents experienced. The loss of land left Māori without a way to make a living. Loss of culture and language left Māori looking for an escape. When you have whole collectives that have been traumatised, they need to have some kind of out. You end up with issues of alcoholism, you end up with issues of drugs, you end up with up with issues of cigarette smoking. Abuse, eating bad food, unemployment - all those things accumulate around inter-generational experience of trauma'. ${ }^{4}$

The literature that adopts these themes of inherited cultural trauma, ongoing colonisation, ongoing state oppression of Māori, and the consequent ongoing requirement for struggle and resistance against, and liberation from colonisation ${ }^{5}$ (which at certain junctures also encompasses elements of what has become known as Kaupapa Māori theory - a model that variously codifies, explains, and prescribes a means of overcoming this trauma) is the focus of this work, viewed through the conceptual lens of Nietzsche's model of ressentiment.

The reason why Nietzsche's version of ressentiment offers such an important theoretical perspective for analysing the belief in inherited colonial trauma is his prediction for where such views end: the self-destruction of the very basis and legitimacy of that trauma. Nietzsche identified the values that 
derive from ressentiment as objectionable, and this paper surveys aspects of that stance in relation to the literature under review. ${ }^{6}$

However, rather than explore the 'validity' of inherited colonial trauma or Kaupapa Māori theory from specifically ideological, historical, or cultural viewpoints (and there is a considerable quantity of deficiencies that can be exposed through each of these perspectives), what is examined here is the efficacy of applying Nietzsche's construct of ressentiment as a psychological explanation for the ideological orientation of the stances exhibited in this literature. This paper has no pretensions to surveying Nietzsche's works in this area in anything like a comprehensive fashion. Their complexity, and the opportunities they afford for exploration and interpretation from numerous angles prohibit this in a work of this scale. Instead, the approach here is one which relies on a selection of thematic elements relating to ressentiment that serve to provide a sometimes impressionistic conceptual framework to interpret the literature in question.

The theoretical integrity of the literature on inherited colonial trauma is at the centre of this analysis. What is evident even from a cursory review of the construct in this context is that it is undermined by the absence of any consistent, recognised psychological application of the term 'trauma'. This deficit in a clinical understanding of trauma is compounded by the majority of those who deploy the term in the literature not being qualified in psychology, and utilising the notion in often arbitrary and sometimes even contradictory ways. It is therefore unsurprising that use of the term in the literature on inherited colonial trauma is often nebulous, and tends to be shaped around the various ideological positions adopted in the literature. The elasticity and imprecision of the constructs of trauma in these works therefore result in the ideas of trauma resting largely on intuitive interpretations, with their rhetorical bases often supplanting more substantive clinical 
understandings of the term. Consequently, 'trauma' ends up serving as a proxy for a range of other ideas.

The following section of this work sketches an outline of the aspects of ressentiment as Nietzsche depicted them. From there, four dimensions of this construct of ressentiment are discussed, and their intersection with notions of the inherited colonial trauma is examined and critiqued.

\section{A Note on Trauma and its Inheritance}

For a body of literature that focuses on inherited colonial trauma, there is surprisingly little awareness of the nature and causes of trauma, or perhaps not so surprising given some of the conclusions reached in that literature. The purpose of this section is to provide a cursory survey of what trauma is, and how it is (and is not) acquired. The function of this article, as a whole, is not to delve into the psychology of trauma, but to test the claims made by proponents of inherited cultural trauma. In the course of exploring the latter, some consideration must therefore be given, at least in overview, of what trauma is, and importantly, the bases of its causes.

The sort of psychological trauma being dealt with here, in a general sense, encompasses a spectrum of psychiatric disorders, which can be caused by a single event or a prolonged experience, and which to some extent are dependent on the pretraumatic attributes and resilience of the victims. ${ }^{7}$ The clinical literature in this field makes it clear that trauma is the result of a direct experience of events that are 'unbearable in their horror and intensity', 8 and that cause 'acute distress', which produces significant and ongoing disruption in the sufferers' ability to function. ${ }^{9}$ Trauma emerges from the 'intense fear, horror, and helplessness', accompanying the experience. 10 Crucially, it is this emphasis on direct experience that is at the core of trauma diagnoses. ${ }^{11}$ Those who have experienced trauma will have directly 'survived' the experience that caused their trauma, ${ }^{12}$ as opposed to the argument applied by the 
advocates of inherited colonial trauma, in which the trauma is acquired through hearing or otherwise learning about an event from someone else.

The deficiency with notions of inherited colonial trauma extends beyond the fact of the traumatic event not being experienced, to the absence of any systematic data on the scope and severity of this alleged trauma. This is particularly telling given the substantial literature on the neuroscience of trauma, ${ }^{13}$ which allows for trauma to be identified and diagnosed through 'standard clinical practice'. ${ }^{14}$

One of the salient features in the literature on inherited colonial trauma is the extent to which the clinical definitions of trauma have been sidestepped in favour of an alternative notion that seems to be shaped to fit the theory. Indeed, in some instances, it is plainly evident that the use of the term 'trauma' in this literature goes as far as being a serious misrepresentation of the term, to the extent that its original clinical application does not apply.

Advocates of inherited colonial trauma rely on sourcing claims of trauma from events that they have not directly experienced. Instead, the basis for the trauma they allege rests with the kinds of self-consciously ideological narratives of nationalist history...[which] assert the existence of some national trauma'. This, in turn, relies on a narrow definition of national identity 'constructed around injuries that cry out for revenge', in the sense Nietzsche suggested. Such constructs produce 'angry' nationalist groups which assert that they were 'injured or traumatized by agents of some putatively antagonistic ethnic and political group, which must then be battled against in turn'. ${ }^{15}$ The sort of imagined trauma referred to here resonates remarkably closely with that detailed by the advocates of inherited colonial trauma. As Alexander warns, such claims represent a 'completely illusory, nonempirical, nonexistent quality of the original event', which involve 'exaggerations that serve obviously aggressive and harmful political forces'. ${ }^{16}$ It is Nietzsche's construction of ressentiment 
that helps to provide a conceptual lens through which the origins of such sentiments can be traced and understood.

\section{Ressentiment}

The word ressentiment - which Nietzsche viewed as one of the most deeply-rooted and powerful influences in society - is similar to the English term 'resentment', but with a stronger, more sharper-edged meaning. At its core is a psychology of blame, in which those who suffer from ressentiment see themselves existing in a hostile external world. ${ }^{17}$ Resentment can be a legitimate and rational response to a wrong committed against someone, and can be overcome by whatever is perceived to be a fair resolution to the injustice by those involved. Ressentiment, on the other hand, is an enduring condition, characterised by repressed feelings towards those identified as dominant, to the point where reactions against the dominant become justified, regardless of how severe or irrational. This festering vengefulness is based on a combination of what Nietzsche identified as envy and impotence. ${ }^{18}$

Psychologically, the construct of ressentiment achieves several functions: it produces rage and self-righteousness as a means of overcoming hurt; it conjures up an offender who is responsible for this hurt; and it creates a 'site of revenge to displace the hurt' - that is, the tendency to inflict hurt against a certain object in a way that the sufferer believes represents the hurt that has been directed against them.19 Moreover, ressentiment can also sublimate personal traumas into collective political or historical ones, thus projecting the personal as political, and thereby ideologising the personal through a collectivising process. Ressentiment consequently allows the loathing of the self to be redirected into a loathing of others, in the course of which the weak rationalise their own weakness by inversely (and perversely) privileging it as morally superior to the strong. ${ }^{20}$ 
Those who perceive themselves as being persecuted thus acquire virtue solely by being persecuted, and consequently, the act of seeking persecution (real or imaginary) becomes a requirement for maintaining the ensuing virtue. A causative relationship is formed as a result, by which not only the sense of persecution is a prerequisite for moral superiority, but by which the intensification of the former leads to the amplification of the latter. Ressentiment is therefore not a static state, but one which spirals down to the eventual self-destruction of the persecuted'. As Nietzsche put it in Ecce Homo, 'Nothing burns one up faster than the affects of ressentiment. Anger, pathological vulnerability, impotent lust for revenge...such affects involve a rapid consumption of nervous energy, a pathological increase of harmful excretions....Ressentiment is what is forbidden par excellence for the sick - it is their specific evil - unfortunately also their most natural inclination'. ${ }^{21}$ It is precisely this fearful terminal point of ressentiment that makes it so significant, to the extent that it offers a prescriptive dimension to the literature under review here, and also suggests the ideological trajectory contained in that literature.

There are several dimensions of ressentiment that are applicable here in the context of an analysis of that body of ideas which deals with an interpretation of New Zealand's colonisation, and its presumed nature and effects in terms of generating inherited colonial trauma for Māori. Nietzsche's construction of the idea of ressentiment, is divided for this purpose into four constituent parts, each of which is subsequently used as a category for analysing and interpreting the basis of claims made in that literature that advances the narrative that colonisation is an ongoing and traumatic aspect of the lives of all Māori. These four dimensions ${ }^{22}$ are described in a largely skeletal fashion here, because of the large and intricate sets of intersecting ideas that Nietzsche brings to bear on each aspect of ressentiment, and particularly the singular perception of history he assembled to account for their inception. 
In the context of this paper, it is the claimed suffering of people several generations removed from an event (which incidentally potentially belittles the trauma of those who actually experienced the suffering) that is both the starting and termination points of the analysis. In particular, the trajectory of ongoing (and in some instances even intensifying) suffering that the literature dealing with the inherited colonial trauma emphasises, converges closely both with the elements and the stages of Nietzsche's construction of ressentiment.

\section{Ressentiment emerged as a reaction by the oppressed (the 'slaves') to their suffering.}

The suffering endured by many Māori during the second half of the nineteenth century in New Zealand, principally as a consequence of their entanglements ${ }^{23}$ with settler society, has been well-documented. ${ }^{24}$ Some of the most horrendous examples occurred during the course of the New Zealand Wars. The atrocities committed against certain Māori hapū and iwi (sub-tribes and tribes) were severe, and included the destruction of homes, villages, livestock, and crops; mass confiscation of land; and large scale loss of life to such an extent that the survival of some tribal groups was severely threatened.25 Moreover, the end of the wars between certain Māori and the settler government did not lead to a cessation of the suffering. On the contrary, both the incidental and planned consequences of the conflict included ongoing land loss, 26 extreme poverty, starvation, disease, and ongoing racism. ${ }^{27}$

In Nietzschean terms, these sorts of experiences could be categorised as 'legitimate' suffering, on the basis that the suffering was directly experienced by the affected group, and that the group subsequently had to suffer the consequences of these events. It would be misguided, though, to presume that the suffering ceased when this generation passed away. The legacies of land loss, lack of access to education and health 
facilities, few economic opportunities, and discrimination persisted to some degree in later generations.

However, it would be equally misguided to presume that this suffering was experienced in equal measure by all Māori, and in all subsequent generations. To think this would be to ignore the ameliorating effects of several historical developments that have taken place since that era, as well as the fact of some hapu and iwi not having suffered in any excessive way during the wars, but actually even benefitting from them, usually through aligning with the Crown in some of the conflicts. ${ }^{28}$ Yet, ignoring such historical factors is precisely what has happened in the bulk of the literature dealing with the alleged inherited colonial trauma. Taonui, for example, offers a generic depiction of the source of this trauma - one which ignores the nuances of history, and the often substantial variation in hapu and iwi experiences in favour of a form of imprecise historical universalism. He states (with forced alliteration), that 'Māori were subjected to war, confiscation and forced sale of land' and that Māori also suffered 'demographic decline, driven by disease, destruction, dispossession, disenfranchisement, disempowerment, dismemberment of culture, and despair'. ${ }^{29}$

Like some inversion of the Whig approaches to history, ${ }^{30}$ this construct can easily be criticised for its oversimplification of the relationship between the past and present, for its polemical tone, and for extracting events from their historical settings and applying subjective and inconsistent measures of evaluation to them, and for its inaccuracies. ${ }^{31}$ The literature that deals with inherited colonial trauma is like a mirror-image of the Whig approach to histories, because in addition to these deficiencies, it presents New Zealand history from the eighteenth century to the present time as part of a linear progression of Māori subjugation, with all the methodological deficiencies that have been detailed in relation to this approach. ${ }^{32}$ 


\section{History is explored not to understand the nature of the past as much as to shape renditions of the past to feed the sense of ressentiment in the present}

The misappropriation of history to aid feelings of ressentiment is one of the key features of the works of those who subscribe to the idea of inherited colonial trauma. How the need for this historical misappropriation manifests itself was detailed by Nietzsche. Those who are 'suffering', he writes, are:

dreadfully eager and inventive in discovering occasions for painful affects. They enjoy...dwelling on nasty deeds and imaginary slights; they scour the entrails of their past...for obscure and questionable occurrences that offer them the opportunity to revel in tormenting suspicions and to intoxicate themselves with the poison of their own malice: they tear open their oldest wounds, they bleed from long-healed scars. ${ }^{33}$

More generally on the issue of remembering the past, what Nietzsche terms as the 'slave' is held hostage by their memories, and does not know how to forget. 34 Consequently (from Ecce Homo): 'One cannot get rid of anything, one cannot repel anything - everything hurts....experiences strike one too deeply; memory becomes a festering wound', 35 whereas for the 'noble man', even if a moment of ressentiment occurs, it exhausts itself in an immediate reaction, and therefore does not poison'. 36

The portrayal of histories which strip away all the context that does not focus on colonial trauma and its concomitant pseudo-psychological effects generations later illustrate the way in which such accounts can hold the subject group hostage as Nietzsche argues. The following two examples reveal these traits of 'dwelling on nasty deeds' through remaining largely devoid of a more contextualised, nuanced, and historically balanced analysis in favour of appropriating history to fuel notions of ressentiment: 
Psycho-social domination was achieved using strategies such as land purchase, warfare, land confiscation, legislation, religion, and the imposition of non-Māori cultural and social practices. ${ }^{37}$

Gross speaks of 'post-apocalyptic stress syndrome', [which is] when a culture experiences such a massive shock that it never fully recovers. This brings to mind the dysfunction we see in many indigenous cultures today, post colonisation. ${ }^{38}$

But at what stage did this inherited colonial trauma commence in New Zealand? The answer is from the onset of colonisation, according to those laboring under their imagined inherited colonial trauma. During the first half of the nineteenth century in New Zealand, rapid modernisation (in the sense of the term used by Rostow and Smelser) ${ }^{39}$ brought about changes that were both tumultuous and prosperous for some tribal groups and settlers. ${ }^{40}$ The period was characterised by developments including a rapid growth in trade, the introduction of capital into the country's economy, a shift in the organisation of the factors of production, a change in traditional production functions, ${ }^{41}$ the adoption of European skills, knowledge and technology by hapū and iwi, ${ }^{42}$ intermarriage, ${ }^{43}$ disease, ${ }^{44}$ and new forms of warfare. ${ }^{45}$ However, much of the literature produced by the advocates of inherited colonial trauma suggests that the encounters between Māori and coloniser were universally negative for the former. Taonui, for example, suggests that:

Māori faced systematic economic, political, social and cultural marginalization, cultural alienation, forced assimilation, demonization, racism, structural prejudice and intergenerational impoverishment. Māori language was banned, their culture, heritage and identity decimated. ${ }^{46}$ 
Putting aside the unusual suggestion of a culture, heritage, and identity somehow being measurably reduced by ten per cent, this universalist account depicts colonisation as being inherently oppressive, and focused on consciously undermining the status and authority of hapu $\bar{u}$ and iwi. ${ }^{47}$ The evidence suggests clearly that such a binary 'good-bad' dichotomy is inaccurate, and that the nature of interactions between tribal groups and British settlers encompassed a broad spectrum of experiences, and further, that these relationships were far more nuanced and intricate than much of the literature on inherited colonial trauma suggests.

One example that illustrates this is the acquisition of literacy by hapu and iwi. There is little doubt that the arrival of the written word in New Zealand altered tribal society and impacted on indigenous oral traditions. ${ }^{48}$ However, Māori were not simply passive victims of literacy but rather, actively embraced print culture, reading, and books. Enthusiastic reports were sent back to London by missionaries and other settlers of the 'remarkable desire of the Maori to learn to read, the further stimulation of that interest through native teachers, the intense and apparently insatiable demand so created for books' ${ }^{49}$ Learning that occurred in schools migrated into Māori communities where there were no schools, and the more literate that Māori readers became, the more their perceptions and knowledge expanded. Similarly, the more printed material that became available, the broader the conceptual horizons of readers became. 50 An early trader observed: 'If one native in a tribe can read and write, he will not be long in teaching the others. The desire to obtain this information engrosses their whole thoughts, and they will continue for days with their slates in their hands'. ${ }^{51}$ This begs the question: was the introduction of literacy a fatal impact form of colonisation or the exercising of agency and foresight by Māori? Numerous sources produced by the advocates of inherited colonial trauma suggest it is the former, 52 arguing that literacy was a powerful weapon in colonial attacks on tribal groups, and aimed at the deliberate 
and sustained usurpation of tribal sovereignty, despite the fact that the evidence points to the opposite being true.

The following example from McRae illustrates how the history of literacy in nineteenth-century New Zealand has been shaped to represent literacy as a tool of oppression:

\begin{abstract}
Māori use of writing and print in the 19th century occurred in a time of profound, often aggressive change. If writing had been introduced without colonisation and Māori had chosen at their own pace and in their own way how, even if, to use these arts, there would have been a different story. But very soon after the introduction of writing, Christianity and British government were exerting considerable force on their way of life. ${ }^{53}$
\end{abstract}

In making this argument, the author has had to rely on the non sequitur of writing being 'introduced without colonisation', and then ignores the extent to which Māori controlled the rate and nature of the spread of literacy in this era, before claiming that 'very soon' after the introduction of literacy, the British government was exerting 'considerable force' on Māori. However, historically, literacy was introduced a full quarter of a century before British government was established in the colony, and even when it was established, it barely affected most Māori communities at that time (and certainly did not exert 'considerable force' often until decades later). The point here is that in order to adhere to the ressentiment model, some significant adjustments to the historical record are sometimes required.

Similarly, Walker addressed the history of colonial-era literacy in a manner that couched it to serve feelings of ressentiment:

The transition from oral to written transmission of knowledge was an enterprise fraught with ambivalence and potential danger. In Māori epistemology, humans are born into the world with no knowledge. All knowledge emanates from the gods, who embedded it in the natural 
world to be discovered by humans. For this reason, the pursuit and transmission of knowledge was a sacred enterprise confined to whare wānanga. ${ }^{54}$

Māori agency, in this extract, is minimised in order to support the narrative that Māori either had literacy somehow forced upon them, or that they unwittingly adopted literacy to the detriment of their culture - a view that, among much else, relies on a construct of culture that is artificially static.

Walker then paradoxically claims that the near absence of Māori agency was supplanted by an agency that was subverted by missionaries, who monopolised the literature Māori read:

The Māori desire to access Western knowledge was thwarted by missionary control of the curriculum. Instruction in the mission schools was strictly confined to the scriptures, and reading and writing in the Māori language only. Secular and non-Christian knowledge was excluded from the curriculum. English was not taught because the missionaries did not want Māori contaminated by non-Christian influences. ${ }^{55}$

Even a brief survey of the literature in Te Reo in the colonial era shows this to be entirely incorrect. Māori not only read on a broad range of secular as well as sacred topics, but crucially in the context of Walker's argument, produced an enormous quantity of written material in this period.

Similar patterns are found throughout the literature on inherited colonial trauma, where there is a tendency to argue that trauma passed down from the colonial period relies on a generic historical experience shared by all Māori in the nineteenth century.

There are numerous instances of this revisionist approach to history which fail to recognise individual tribal experience, and rather, suggest a homogenous history that obscures hapu and iwi differences. In the case of the New Zealand Wars, for example, some Māori communities benefitted from their involvement in the conflicts, and were awarded substantial 
blocks of confiscated land as payment for their loyalty to the Crown. ${ }^{56}$ Yet, in the literature of those advocating for inherited colonial trauma, the character of conflict and land confiscation experienced by Māori during the wars is depicted as being universal, 57 and resulted in a form of widespread and ongoing trauma that applied to all Māori, and that has endured to the present today. The obvious methodological flaw in such an approach is that it only has a semblance of validity provided that a highly selective and even exaggerated form of history is utilised to support it. Pihama's representation of the colonial era epitomises this practice of producing a generalised construction of history to support a ressentiment sentiment:

It has been advocated that the State is the greatest perpetrator of violence upon Māori. The dispossession of land through colonial acts of confiscation... continue to manifest as both historical and colonial trauma, and in the current state of homelessness and disconnection to land and place experienced by Māori. ${ }^{58}$

Such reshaping of renditions of the past has been necessary to give birth to a narrative of historical trauma ${ }^{59}$, which ostensibly passes from generation to generation. 60 Historical trauma is understood in this literature as 'cumulative emotional and psychological wounding, over the lifespan and across generations, emanating from massive group trauma experiences' 61 , and is said to manifest in a range of dysfunctional behaviours, which influence the learning environment' of subsequent generations. ${ }^{62}$

In addition to necessarily lacking any contextual historical precision, the language associated with the inherited colonial trauma sometimes diverges into even more nebulous, esoteric territory, using terminology such as 'spiritual injury', 'soul sickness', 'soul wounding', and ancestral hurt,'63 and in other instances, relies on terms that are used in ways that defy their legal or historical definitions, such as 'genocide'64, 'ethnocide', 65 and 'holocaust'.66 Then there is the exaggeration-prone 
terminology, such as 'cataclysmic, massive collective traumatic events... and unresolved grief' 67 ; and the almost meaningless 'historical disenfranchised grief'.68 Some authors argue that 'colonial invasion', which sought to 'annihilate or destroy Indigenous peoples', constitutes an act of genocide, and broadly state: 'This is the experience of Māori people'.69 Putting aside the unquantifiable or intangible nature of some of this rhetoric, there are significant historical and legal deficiencies with this approach.

So while it is beyond dispute that atrocities were committed against some hapu and iwi in the nineteenth century, it is equally beyond dispute that this was not the case for all tribal groups. Therefore, for many Māori in contemporary New Zealand, what is the source of their 'trauma' if not through a directly causative link to a site or occurrence of actual trauma? According to the inherited colonial trauma literature, it would seem that some Māori have adopted a sort of 'prosthetic suffering, which is necessarily exaggerated, often fabricated, and intentionally misrepresented in order for the narrative of inherited colonial trauma to function. Yet, the denial persists as part of the ressentiment narrative:

Modern New Zealand is built on dispossession and past indigenous suffering. This is not interpretation, it is history. The scale of dispossession and suffering was culture-wide and national, with land dispossessions, bloodshed, destruction of marae, theft of cultural artefacts, denial of culture and language, etc. These abuses are well documented, and are a well-worn path in the history of colonisation. This is what colonisation is. ${ }^{70}$

The manipulation of historical evidence to produce this historical trauma discourse has resulted in many of those who embrace it being held captive in a false reality built on an inaccurate reconstruction of the past. Contemporary 'understandings' of colonial oppression have become 'integrated into the psyche and soul Māori [sic]',71 where perceived notions 
of 'trauma' fuel a fire of ressentiment. This, in turn, requires the construction of a moral adversary, as Nietzsche prescribed, ${ }^{72}$ because the person who possesses this ressentiment 'has conceived 'the evil enemy,' 'the Evil One,' and this is his basic concept, from which he then evolves, as an afterthought and pedant, a 'good one' - himself!'73

\section{Ressentiment encourages the sufferer to attack what they see as the cause of their suffering}

"I suffer: someone must be to blame for it". ${ }^{74}$

Friedrich Nietzsche

Absent from the literature addressing the causes of inherited colonial trauma - those causes being the:

historic or intergenerational traumatic experience of, for example, veterans or victims of war, genocide and other forms of subjugation, discrimination or abuse including collective loss of land, language, culture and identity or integration, assimilation and segregation policies ${ }^{75}$

is any mention of pre-European traumatic events such as intertribal conflict, land and resource loss, enslavement, and large-scale loss of life, including through war, infanticide, and cannibalism. ${ }^{76}$ Instead, trauma is (suspiciously) solely attributed in the literature on inherited colonial trauma to phenomena associated with colonisation and the actions perpetuated against the generic construct of 'Māori' by British settlers. It would seem, therefore, that internal, tribal sources of trauma are obviated, and external, colonial sources of trauma are correspondingly exaggerated and distorted. This behaviour feeds the third dimension of Nietzsche's ressentiment, where the notion of 'blame' is a common theme in much of the literature, and where 'blame' manifests as attacks on what the proponents of inherited colonial trauma see as the cause of their suffering. 
The following extracts typify the element of blame in this literature:

Most Māori commentators believe that the origins of the violence [against children] stem from colonization. ${ }^{77}$

This brings to mind the dysfunction we see in many indigenous cultures today, post colonisation. [There are] similarities between post-14th century Europe, which suffered the cataclysm of the Black Death, and the indigenous experience of colonisation. Both resulted in an intergenerational pandemic of post-traumatic stress disorder, suicide and widespread substance abuse. ${ }^{78}$

Māori exposure to historical trauma has had a massive impact on Māori well-being across multiple generations. It began with the loss of entire communities during the land wars and was maintained by the incapacitation of social, cultural and economic autonomy through land loss and pyscho-social domination. Legal imperialism facilitated the loss of language and cultural practices and damaged protective social structures and interpersonal relationships within Māori families and communities. These processes exposed Māori to chronic and complex trauma precipitating the development of physical and psychological conditions across generations. Moreover, they ruptured the sacredness of relationships between men and women and destroyed the nurturing protective environments required for child rearing. In short, the accumulative impact of historical trauma on Māori wellbeing has been severe and understanding this history is especially important at present as Māori are suffering from high rates of exposure to physical, sexual and psychological abuse. ${ }^{79}$

Implicit in many sources of this literature is that historical and ongoing colonisation is the cause of contemporary trauma experienced by Māori, with one author arguing that ' $[t]$ he seed that grew to become historical trauma was planted at the time of colonisation'. 80 Colonisation ostensibly causes a detrimental 
impact on Māori identity, 81 exacerbated by changes to the economy, workforce, and 'rural farming lifestyle', which prohibited the maintenance of 'traditional Māori identities'. 82 It is further suggested by these advocates of inherited colonial trauma that these changes led to the decline of the Māori language and cultural practices, and aided the colonisation of Māori values and knowledge. ${ }^{83}$ In addition, the loss of land, resources, and economic stability has had a long-term subsequent effect on Māori health outcomes. ${ }^{84}$ One study argues that an increased risk of exposure to violence and abuse within Māori communities, and high Māori suicide rates are 'a reflection of the trauma of colonisation transmitted, as trauma often is, through generations' ${ }^{85}$ It is also suggested that colonisation causes internalised anger, with the dangerous implication that it is the reason for high rates of child abuse in Māori communities:

\begin{abstract}
We rarely recognize that colonization and its concomitant intergenerational impacts constitute violence: colonization is the application of anger upon vulnerable peoples. This violence has a reciprocal reaction within the societies upon which it is inflicted: cultural alienation, forced assimilation and cumulative marginalization create anger in indigenous societies. Where this anger is not understood, it becomes internalized within the colonized society and inverts upon itself. The indigenous oppressed attack each other. Angry men fight each other, sometimes in gangs, the red fights the blue. Anger seeks the weak and vulnerable in the form of mothers and children, violence expresses itself by seeking innocence. 86
\end{abstract}

This extract could be interpreted as being inherently racist in its suggestion that Māori lack sufficient agency or emotional capacity to respond in any other way but violently. It also seems to rest, ironically, on nineteenth-century Pākehā constructs of Māori as being somehow more savage than their European counterparts. Furthermore, it evokes the question of whether a 
collective sense of dispossession and trauma can cause a people to commit crimes against their own partners and children. The links are not only unproven, but unexplained and appear extraordinarily tenuous. Crucially in this context, colonisation, dispossession, and trauma have been the fate of every society at some point in history. Certainly, every culture on earth has undergone dramatic transformation in the last three centuries, largely as a result of the impact of and interactions with other cultures, and of industrialisation. The only variable is the rate at which these transformations occurred, not the fact of them occurring. However, a culture of blame traps those who adopt it in a cycle of excuse-making and ressentiment at both the fact and the causes of these changes. It is a 'self-poisoning of the mind' as Scheler described it, 87 and in New Zealand's case, paints the consequences of such transformations and events as exclusive to Māori as opposed to what history shows as being universal to all cultures and peoples. The notion of historic dispossession, in particular, resonates with the belief that the source of ressentiment is lodged in a 'thirst for revenge' which emerges from frustration, and is 'provoked by a combination of envy for what one does not have and impotence to obtain it'. 88

The culture of blame manifests itself in angry attacks on the perceived cause of suffering, where the group lashes out, making what are often sweeping generalisations against the system, and even against an entire ethnic group. The following extracts illustrate this intersectionality of blame and anger:

I hate elections. They are the epitome of colonial control. A year when the height of white privilege is guaranteed to reign supreme in its effort to demean anything Māori.... In election year, anything and everything Māori is considered a target. There are the predictable issues, the Māori seats, Treaty Rights, Māori engagement with health, education, social welfare, justice. Then this year we can add the attack on Whare Wānanga by a bunch of overly entitled universities led by overly privileged white men who assume that white knowledge is the only knowledge worthy of transmission in a higher education 
context.... It seems that everywhere I turn there is a (sic) upsurge of white supremacy expressed as white privilege. ${ }^{89}$

In a country where colonialism is as ubiquitous as the air we breathe most would have no IDEA what it would look like to have an equally Māori and Pakeha world. So don't throw your meagre brown crumbs at me and tell me to be thankful for biculturalism.... My people are not yet free. We are not free to live the lives that our ancestors did - nor are we free to secure the choice of which aspects of their world we carry forward for our descendants. We are not free to live on our tribal lands. We are not in control of our representations. We are not in control of our own wellbeing. We are not in control of our own healing, or our own governance. So don't talk to me about biculturalism. ${ }^{90}$

Old white men have been living off priveledge [sic] and degrading, oppressing and exploiting other demographics from time immemorial. The merest flick of an (overdue) backlash and you go all "poor me!"91

In such examples, the ressentiment is palpable. They epitomise the experience of 'those who serve and are dominated, who fruitlessly resent the sting of authority'. ${ }^{92}$ The dominated use their repressed feelings - as expressed in such outbursts - to validate and legitimise their reactions against the dominant. ${ }^{93}$

\section{Ressentiment ameliorates (what Nietzsche calls 'anaesthetize') and externalises what would otherwise be 'unendurable'. 94}

Ressentiment, as Nietzsche construed it, is not a static state. It gradually escalates into a more intense form before finally imploding. In this more intense condition, there is a sense of 'feeling backwards' - that is, having one's present cultural and psychological state determined by a cognitive relation to a past event'. ${ }^{95}$ Nietzsche prescribed how ressentiment plays out in this 
stage. It goes beyond just an inclination to react to an imagined harm, and strives towards an inclination to seek out something that can be plausibly regarded as the cause of one's suffering. ${ }^{96}$ Armstrong makes this point explicitly:

The extent of loss that Māori suffered was extensive [sic], including loss of language and cultural paradigms. It involved the loss of political and legal power as well as the structures fundamental to Māori life, that of whānau, hapu and iwi. The losses were also experienced in the loss [sic] of land, food security and the ongoing production of wealth.... A Native American writer, Brave Heart, describes a key element of historical trauma as "disenfranchised grief", grief that is unacknowledged and un-mourned. This un-mourned grief can be carried through into further generations and has many social impacts. ${ }^{97}$

The point here is that those experiencing ressentiment aim to find some target for an act of revenge, even if it is not necessarily the actual cause of their suffering: 'A scapegoat targeted "on some pretext or other" is much better than no target at all'. 98

In his typically brutal rhetorical style, Nietzsche provides a graphic depiction of the extent to which ressentiment engulfs the whole of the person experiencing it: They are all men of ressentiment, physiologically unfortunate and worm-eaten, a whole tremulous realm of subterranean revenge, inexhaustible and insatiable in outbursts against the fortunate and happy and in masquerades of revenge and pretexts for revenge'. 99

For this persecuted group, their antitheses in society are necessarily evil, corrupt, dominating, aggressive, and according to one writer, as a consequence, Māori 'can not remove ourselves from a context of colonial oppression within which we struggle every day'. 100

However, envy and contempt for the enemy induces selfloathing to the point where the weak lash out, ironically, at those who are less powerful than themselves, which in practice 
can mean other members of the same group. And if there are those in this persecuted group who, paradoxically, assume positions of power, status, or responsibility in the very society they believe is persecuting them, they justify this ascent either as a ploy to subvert the enemy from within, or as something that is irrelevant to the essence of their struggle. This latter stance is significant in that it represents a form of cognitive dissonance.101 The ideology associated with the inherited colonial trauma conveniently bypasses such contradictions.

\section{Conclusion}

Unavoidably, Nietzsche's construct of ressentiment can appear as an unsettling means of analysing the ideological and values bases of the literature of inherited colonial trauma, as is done here in a specifically New Zealand context. Part of the reason for this is that Nietzsche undermines conventional ideas about values and morality. Compassion, empathy, and pity, for example, are condemned by him as being part of a slave morality. Less controversial in a post-modernist age, but ironically potentially just as subversive to the absolutism of the notions of inherited colonial trauma, is Nietzsche's renunciation of the possibility that any of these values are valid universally. ${ }^{102}$ Yet, despite these attributes of Nietzsche's construct of ressentiment, its descriptive and prescriptive utility in the context of the arguments about colonisation and the enduring trauma supposedly associated with it remain.

The narrative of inherited colonial trauma has the potential to trap those who believe it in a downward spiral of blame, anger, and ressentiment. What will break this cycle of despair? How will historical and intergenerational trauma be resolved, and what indicators will be used to determine when this has been achieved? What role does decolonisation play in freeing Māori from the shackles of inherited colonial trauma - where decolonisation is a complex and seemingly impossible goal? How will Māori exercise agency and tino rangatiratanga - an act 
that one commentator describes as a 'utopian vision'103 - in a society that the advocates of inherited colonial trauma argue is continuously controlled by the coloniser? In other words, if decolonisation is indeed impossible, and it is supposedly ongoing colonisation that adds to the trauma experienced by Māori, Māori seem destined to remain entrapped permanently by that trauma, and compelled to fight in a 'Struggle Without End'. This suggests that the claimed trauma is, in fact, no trauma at all, on the bases that it cannot be healed through the normal process of treatment, that it can be only amplified rather than reduced (despite the causes not having been experienced by the individuals claiming the inherited trauma), and that the 'diagnosis' of the trauma is done in the near-absence of any clinical expertise by the proponents of inherited colonial trauma.

What is also noticeable in the accounts of inherited cultural trauma is that it tends to be a reaction in the individual to narratives that they have read or accounts that they have heard of historical events, rather than existing as a form of trauma produced by direct personal experience. To this extent, the cause of the trauma is manifestly learning about something that happened to others, rather than experiencing something directly. Inherited colonial trauma therefore can only function as a legitimate form of trauma if this distinction is concealed, which tends to be the practice in most of the literature on the topic.

Even if the historical, psychological, epistemological, ontological, and methodological deficiencies that undermine the literature on inherited colonial trauma are set aside, the premise of the concept still suffers from the range of flaws revealed in Nietzsche's construction of ressentiment. Specifically, this type of prosthetic trauma includes the traits of conjuring in the imagination a sense of deeply-felt inherited trauma, seeking a cause of that suffering, shaping history and the nature of the world in a manner that conforms to the need to experience trauma, identifying a group which is 'responsible' 
for this trauma, and developing a desire for vengeance - but importantly, one that can never be satiated.

This is the axiomatic flaw with the literature on inherited colonial trauma: that it constructs an entire framework which is incapable of allowing any escape from that trauma. Instead, it offers adherents to the idea only endless suffering, and endless struggle as the price to pay for being indigenous. This formula only functions, as has been demonstrated, through a combination of the denial of Māori agency and rangatiratanga, through the selectivity and distortion of the historical record, and most concerning, through the sublimation of individual personal trauma, into collective cultural trauma. As has been evidenced, inbuilt into this ressentiment is the inability, as Nietzsche noted, for the 'trauma' ever to be overcome, and to this extent, it can only be detrimental culturally.

\section{Postscript}

During the course of writing this paper, we had discussions with Māori from various iwi around the country. These people ranged considerably in gender, age, education, and income levels, yet not one of them said that they had inherited colonial trauma, and most found the suggestion offensive. Of course, this is not necessarily a representative group, and the opportunity certainly exists for the study of a larger sample. However, what is significant about these discussions is that they demonstrate the fact that the claims of inherited colonial trauma applying generically to all Māori (which is common to practically all the literature on this topic) is demonstrably false, and exists as a generalisation without any evidence to support it. Indeed, without sufficient knowledge of the individual circumstances of all Māori, coupled with the absence of any professional diagnoses of trauma for all Māori, the all-encompassing claims of the proponents of inherited colonial trauma are necessarily brought into serious question, not just for their ideological orientation, historical misrepresentation, and the lack of 
clinical expertise to support their claims, but from the absence of any quantitative evidence to support them.

Peer Review Statement:

Journal article blind peer-reviewed by two New Zealand and two international reviewers. 


\section{Notes}

1 As examples of this Marxist influence, see G. Cooper, 'Kaupapa Maori research: Epistemic wilderness as freedom?', in New Zealand Journal of Educational Studies, vol. 47, no. 2, 2012, pp. 64-73; R. Mahuika, 'Kaupapa Māori theory is critical and anti-colonial', in MAI Review, vol. 3, no. 4, 2008, pp. 1-16; G. H. Smith, 'The politics of reforming Maori education: The transforming potential of Kura Kaupapa Maori', in Towards Successful Schooling, 2012, pp. 73-87; Bishop, Russell. "Pretty difficult: Implementing kaupapa Maori theory in English-medium secondary schools." New Zealand Journal of Educational Studies vol. 47, no. 2, 2012, pp. 38-50; T A C. Royal, 'Politics and knowledge: Kaupapa Maori and matauranga Maori', in New Zealand Journal of Educational Studies, vol. 47, no. 2, 2012, pp. 30-37; T K. Hoskins, 'A fine risk: Ethics in kaupapa Maori politics', in New Zealand Journal of Educational Studies, vol. 47, no. 2, 2012, pp. 85-99; L. Pihama, 'Kaupapa Māori theory: transforming theory in Aotearoa', in He Pukenga Korero, vol. 9, no. 2, 2012, pp. 5-14.

2 I. Wallersteon, The Essential Wallerstein, New York, 2000, pp. 35, 272-80.

$3 \quad$ Friedrich Nietzsche, On the Genealogy of Morals, translated by W. Kaufmann and P. J. Hollingdale (New York: Vintage, 1969), p. 127.

4 L. Pihama, in F. Kerr, 'Faces of Innocents: High rates of child abuse among Maori can be traced back to colonisation, academic says', 30 July 2016, in https://www.stuff.co.nz/national/faces-ofinnocents / 82586709/faces-of-innocents-high-rates-of-childabuse-among-maori-can-be-traced-back-to-colonisationacademic-says

5 S. Walker, 'Kia tau te rangimarie: Kaupapa Mäori theory as a resistance against the construction of Mäori as the 'Other'. MA thesis, Thesis, University of Auckland, 1996, p. 119; L. Pihama, 'Kaupapa Māori theory: transforming theory in Aotearoa', pp. 5, 8 .

$6 \quad$ B. Reginster, 'Nietzsche on Ressentiment and Values', in Philosophy and Phenomenological Research, vol. 57, no. 2, June 1997, p. 281.

7 Harvey, Mary R. "An ecological view of psychological trauma and trauma recovery." Journal of Traumatic Stress, vol. 9, no. 1, 1996, pp. 3-4.

8 C. Caruth (ed.), Trauma: Explorations in Memory, Baltimore, 1995.

9 G. A. Bonanno, 'Loss, trauma, and human resilience: Have we underestimated the human capacity to thrive after extremely aversive events?', in American Psychologist, vol. 59, no. 1, 2004, p. 20.

10 J. E. Sherin and C. B. Nemeroff, 'Post-traumatic stress disorder: the neurobiological impact of psychological trauma', in Dialogues in Clinical Neuroscience, vol. 13, no. 3, 2011, p. 263. 
11 Mark I. Singer, et al. 'Adolescents' exposure to violence and associated symptoms of psychological trauma', in Jama, vol. 273, no. 6, 1995, pp. 477-482; B. A. Van der Kolk and O. Van der Hart, 'Pierre Janet and the breakdown of adaptation in psychological trauma', in American Journal of Psychiatry, vol. 146, no. 12, 1989, pp. 1530-40; A. Van Emmerik, et al., 'Single session debriefing after psychological trauma: a meta-analysis', in The Lancet, vol. 360, no. 9335, 2002, pp. 766-771.

12 L. McCann and L. A. Pearlman, Psychological Trauma and Adult Survivor Theory: Therapy and Transformation, Oxford, 2015, p. 3.

13 J. E. Sherin and C. B. Nemeroff, 'Post-traumatic stress disorder: the neurobiological impact of psychological trauma', in Dialogues in Clinical Neuroscience, vol. 13, no. 3, 2011; M. W. Gilbertson, et al., 'Smaller hippocampal volume predicts pathologic vulnerability to psychological trauma', in Nature Neuroscience, vol. 5, no. 11, 2002, 1242-1257; B. A. Van der Kolk, 'Trauma, neuroscience, and the etiology of hysteria: An exploration of the relevance of Breuer and Freud's 1893 article in light of modern science', in Journal of the American Academy of Psychoanalysis, vol. 28, no. 2, 2000, pp. 237 262.

14 A. Van Emmerik, et al., 'Single session debriefing after psychological trauma: a meta-analysis', in The Lancet, vol. 360, no. 9335, 2002, p. 766.

15 J. C. Alexander, 'Towards a Theory of Cultural Trauma', in J. C. Alexander et al. (eds.), Cultural Trauma and Collective Identity, Berkeley, 2004, p. 8.

16 Ibid., p. 9.

17 D. Fassin, 'On resentment and ressentiment: the politics and ethics of moral emotions', in Current Anthropology, vol. 54, no. 3, 2013, p. 252.

18 ibid. p. 253; On the Genealogy of Morals, p. 39.

19 W. Brown, 'Wounded Attachments', in Political Theory, vol. 21, no. 3, August 1993, p. 410.

20 Birns, Nicholas. "Ressentiment and Counter-Ressentiment: Nietzsche, Scheler, and the Reaction Against Equality." http://www. nietzschecircle. com/essayArchive1, 2010, p. 9.

21 F. Nietzsche, Ecce Homo, W. Kaufmann (trans.), Vintage Books, New York, 1967, p. 230.

22 These are a variant of the stages described in S. Jenkins, 'Ressentiment, Imaginary Revenge, and the Slave Revolt', in Philosophy and Phenomenological Research, vol. 96, no. 1, 2018, pp. 194-198.

23 The term is used here in the context defined by Ballentyne. See T. Ballantyne Entanglements of Empire: Missionaries, Maori, and the Question of the Body, Auckland, 2015, p. 15.

24 The work of the Waitangi Tribunal since 1985 has played a central role in detailing these experiences.

25 P. Werry, The New Zealand Wars, Auckland, 2018. 
26 Population', in The Journal of the Polynesian Society, vol. 65, no. 3, 1956, pp. 183-199.

M. Sorrenson, 'Land Purchase Methods and their Effect on Maori

L. Bécares, D. Cormack, R. Harris, 'Ethnic density and area deprivation: Neighbourhood effects on Māori health and racial discrimination in Aotearoa/New Zealand', in Social Science and Medicine, vol. 88, 2013, pp. 76-82.

The first significant example of this was the alliance of Tamati Waka Nene and Patuone with the Crown in the war against Hone Heke.

29 R, Taonui, 'Mana Tamariki: Cultural Alienation', in AlterNative: An International Journal of Indigenous Peoples, vol. 6, no. 3, p. 188.

H. Butterfield, The Whig Interpretation of History, London, 1931.

$\mathrm{K}$. Sewell, Herbert Butterfield and the Interpretation of History, Basingstoke, 2005, pp. 32-40.

as examples, see A. Wilson, Adrian, and T. G. Ashplant, 'Whig history and present-centred history', in The Historical Journal, vol. 31, no. 1, 1988, pp. 1-16; N. R Lamoreaux, D. M. G. Raff, and P. Temin, 'Against whig history', in Enterprise \& Society. vol. 5, no. 3, 2004, pp. 376-387; T. G. Ashplant and A. Wilson, 'Present-centred history and the problem of historical knowledge', in The Historical Journal, vol. 31, no. 2, 1988, pp. 253-274; D. R. Oldroyd, 'Sir Archibald Geikie (1835-1924), geologist, romantic aesthete, and historian of geology: The problem of whig historiography of science', in Annals of Science, vol. 37, no. 4, 1980, pp. 441-462.

K. Sewell, Herbert Butterfield and the Interpretation of History, pp. 127-128.

ibid., p. 38.

F. Nietzsche, Ecco Homo, p. 230.

F. Nietzsche, On the Genealogy of Morals, p. 39.

R. Wirihana \& C. Smith, 'Historical Trauma, Healing And WellBeing In Mäori Communities', in MAI Journal, vol. 3, no. 3, 2014, p. 199.

J. O'Malley, 'NZ built on dispossession and indigenous suffering', 7 October 2017, in http://gisborneherald.co.nz/opinion/3026503$135 / \mathrm{nz}$-built-on-dispossession-and-indigenous

W. W. Rostow, The Stages of Economic Growth: A Non-Communist Manifesto, Cambridge, 1990; N. Smelser, 'The Modernization of Social Relations', in Modernization: The Dynamics of Growth, New York, 1966.

H. Petrie, Chiefs of Industry: Māori Tribal Enterprise in Early Colonial New Zealand. Auckland, 2013.

ibid

V. O'Malley, The Meeting Place: Māori and Pākehā Encounters, 16421840. Auckland, 2012.

T. Bentley, Pākehā Mãori: the extraordinary story of the Europeans who lived as Māori in early New Zealand. Auckland, 1999.

H. Petrie, Chiefs of Industry: Māori Tribal Enterprise in Early Colonial New Zealand. Auckland, 2013.

M. King, The Penguin History of New Zealand. Auckland, 2003. 
46 R, Taonui, 'Mana Tamariki: Cultural Alienation', in AlterNative: An International Journal of Indigenous Peoples, vol. 6, no. 3, p. 189.

47 See M, Penehira, A, Green, L.T. Smith, \& C. Aspin, 'Māori and indigenous views on $\mathrm{R}$ and $\mathrm{R}$ : Resistance and Resilience', in MAI Journal, vol. 3, no. 2, pp. 96-110; L. Pihama, Colonisation is an act of genocide, 22 April 2017, in https://leoniepihama.wordpress.com/2017/04/22/colonisationis-an-act-of-genocide/; M, Jackson, Colonisation and the suffering of children, 29 April 2017, in https://e-tangata.co.nz/commentand-analysis / moana-jackson-colonisation-and-the-suffering-ofchildren/

48 N. Mahuika, 'Kōrero Tuku Iho': Reconfiguring Oral History and Oral Tradition (Doctoral thesis). University of Waikato, 2012, p. 95.

49 D, McKenzie, Oral Culture, Literacy \& Print in early New Zealand: the Treaty of Waitangi. Wellington, 1985, p. 13.

50 ibid.

51 W. Brown, New Zealand and its Aborigines. London, 1845.

52 See K. Jenkins, Te ihi, te mana, te wehi o te ao tuhi: Maori print literacy from 1814-1855: literacy, power and colonization (Doctoral dissertation, University of Auckland, 1991; N. Mahuika, 'Kōrero Tuku Iho': Reconfiguring Oral History and Oral Tradition (Doctoral thesis). University of Waikato, 2012; G. Butterworth, End of an Era: The Departments of Mãori Affairs 1840-1989. Wellington, 1990; R. Walker, Ka Whawhai Tonu Matou: Struggle Without End, Auckland, 1990; B. Haami, Putea Whakairo Mãori and the Written Word, Wellington, 2004.

53 J. McRae, Book \& Print in New Zealand: A Guide to Print Culture In Aotearoa, retrieved from http://nzetc.victoria.ac.nz/tm/scholarly/tei-GriBook-_div3N1082E.html

54 R. Walker, 'Reclaiming Māori education', in J. Hutchings \& J. LeeMorgan (Eds.), Decolonisation in Aotearoa: Education, research and practice, pp. 19-38, Wellington, 2016, p. 21.

55 ibid.

56 R. Boast, \& R. Hill, (Eds.), Raupatu: The confiscation of Maori land. Wellington, 2010.

57 See R, Taonui, 'Mana Tamariki: Cultural Alienation', in AlterNative: An International Journal of Indigenous Peoples, vol. 6, no. 3, p. 187 202; R. Wirihana \& C. Smith, 'Historical Trauma, Healing And WellBeing In Mäori Communities', in MAI Journal, vol. 3, no. 3, 2014, p. 197-210; L. Pihama, Colonisation and systemic violence in Aotearoa, abstract for a public lecture, University of Otago, 30 June 2018; M. Jackson, Facing the truth about the wars, 17 September 2016, in https://e-tangata.co.nz/history/moana-jackson-facingthe-truth-about-the-wars/

58 L. Pihama, Colonisation and systemic violence in Aotearoa, abstract for a public lecture, University of Otago, 30 June 2018.

59 See R. Wirihana \& C. Smith, 'Historical Trauma, Healing And WellBeing In Mäori Communities', in MAI Journal, vol. 3, no. 3, 2014, 
p. 197-210; L. Pihama, P. Reynolds, C. Smith, J. Reid, \& L.T. Smith, 'Positioning historical trauma theory within Aotearoa New Zealand', in AlterNative: An International Journal of Indigenous Peoples, vol. 10 , no. 3, 2014, p. 248-262; K. Lawson-Te Aho, The healing is in the pain: Revisiting and re-narrating trauma histories as a starting point for healing, in Psychology and Developing Societies, vol. 26, no. 2, 2014, p. 181-212.

60 M. Y. H. Brave Heart \& L.M. DeBruyn, 'The American Indian holocaust: Healing historical unresolved grief', in American Indian and Alaska Native Mental Health Research Journal, vol. 8 no. 2, 1998, p. 56-78.

61 S. Yellow Horse \& M.Y.H. Brave Heart, The Takini Network of Denver: A review of the literature: Healing the Wakanheja: Evidence based, promising, and culturally appropriate practices for American Indian/Alaska Native children with mental health needs', in Wellbriety: White Bison's Online Magazine, vol. 6, no. 6, 2005, p. 58.

62 E. Duran \& B. Duran, Native American postcolonial psychology. New York, 1995.

63 E. Duran, Healing the soul wound: Counseling with American Indians and other Native peoples. New York, 2006, p. 15.

64 L. Pihama, Colonisation is an act of genocide, 22 April 2017, in https://leoniepihama.wordpress.com/2017/04/22/colonisationis-an-act-of-genocide/

65 ibid.

66 T. Turia, Keynote address to the annual conference of the New Zealand Psychological Society, 29 August 2000, retrieved from http://www.converge.org.nz/pma/tspeech.htm

67 L. Pihama, P. Reynolds, C. Smith, J. Reid, \& L.T. Smith, 'Positioning historical trauma theory within Aotearoa New Zealand', in AlterNative: An International Journal of Indigenous Peoples, vol. 10, no. 3, 2014, p. 252.

68 M. Y. H. Brave Heart, 'Gender differences in the historical trauma response among the Lakota', in Journal of Health \& Social Policy, vol. 10 , no. 4 , p. $1-21$.

69 ibid.

70 J. O'Malley, 'NZ built on dispossession and indigenous suffering', 7 October 2017, in http://gisborneherald.co.nz/opinion/3026503$135 /$ nz-built-on-dispossession-and-indigenous

71 T. Turia, Keynote address to the annual conference of the New Zealand Psychological Society, 29 August 2000, retrieved from http://www.converge.org.nz/pma/tspeech.htm

72 D. Fassin, 'On Resentment and Ressentiment. The Politics and Ethcis of Moral Emotions', in Current Anthropology, vol. 54, no. 3, 2013, p. 252.

73 F. Nietzsche, On the Genealogy of Morals, p. 3.

74 F. Nietzsche, On the Genealogy of Morals, p. 128.

75 L. Pihama, P. Reynolds, C. Smith, J. Reid, \& L.T. Smith, 'Positioning historical trauma theory within Aotearoa New Zealand', 
in AlterNative: An International Journal of Indigenous Peoples, vol. 10, no. 3, 2014, p. 259.

76 J.P. Blick, 'Genocidal warfare in tribal societies as a result of European-induced culture conflict', in Man, vol. 23, no. 4, 1988, p. 660.

77 R, Taonui, 'Mana Tamariki: Cultural Alienation', in AlterNative: An International Journal of Indigenous Peoples, vol. 6, no. 3, p. 187.

78 J. O'Malley, 'NZ built on dispossession and indigenous suffering', 7 October 2017, in http://gisborneherald.co.nz/opinion/3026503$135 / \mathrm{nz}$-built-on-dispossession-and-indigenous

79 R. Wirihana \& C. Smith, 'Historical Trauma, Healing And WellBeing In Mäori Communities', in MAI Journal, vol. 3, no. 3, 2014, p. 201.

80 K. Lawson-Te Aho, in Waitangi Tribunal to hear claim Maori suicide linked to ongoing effects of colonisation, 9 December 2017, retrieved from

https://www.nzherald.co.nz/nz/news/article.cfm?c_id=1\&objecti $\mathrm{d}=11955867$

81 T. Moeke- Pickering, 'Māori identity within whänau: A review of literature', University of Waikato, 1996.

82 J. Liu \& J. Temara, 'Leadership, colonisation, and tradition: Identity and economic change in Ruatoki and Ruatahuna', in Canadian Journal of Native Education, vol. 22, no. 1, 1998, p. 138150.

83 T. Smith, Turangawaewae: A case study of the colonisation of indigenous knowledge (Doctoral thesis), University of Auckland, 2005.

84 J. Reid, K. Taylor-Moore \& G. Varona, 'Towards a social- structural model for understanding current disparities in Māori health and well-being', in Journal of Loss and Trauma, vol. 19, no. 6, 2014, p. $1-23$.

85 S. Farrelly, T. Rudegair \& S. Rickard, 'Trauma and dissociation in Aotearoa (New Zealand): The psyche of a society', in Journal of Trauma Practice, vol. 4, no. 3/4, 2005, p. 203.

86 R, Taonui, 'Mana Tamariki: Cultural Alienation', in AlterNative: An International Journal of Indigenous Peoples, vol. 6, no. 3, p. 199.

87 M. Scheler, Ressentiment, Milwaukee, 2003, pp. 25-27.

88 ibid., pp. 25-27.

89 L. Pihama, Maori, woman, mother: \#IamMetiria, 9 August 2017, in https://leoniepihama.wordpress.com/2017/08/09/maoriwoman-mother-iammetiria/

90 T. Ngata, WTH Do You Mean, Bicultural? 6 August 2016, in https://thenonplasticmaori.wordpress.com/2016/08/06/wth-doyou-mean-bicultural/

91 Rockinghorse, in $\mathrm{K}$, du Fresne 'I shouldn't have to shut up just because I'm 'male, pale and stale', 31 May 2018, retrieved from https://www.stuff.co.nz/national/104320484/i-shouldnt-haveto-shut-up-just-because-im-male-pale-and-stale 
92 D. Fassin, 'On Resentment and Ressentiment. The Politics and Ethcis of Moral Emotions', p. 252; M. Scheler, Ressentiment, pp. 25-7.

93 M. Scheler, Ressentiment, pp. 25-7.

94 W. Brown, 'Wounded Attachments', p. 410.

95 S. Jenkins, 'Ressentiment, Imaginary Revenge, and the Slave Revolt', in Philosophy and Phenomenological Research, vol. 46, no. 1, January 2018, p. 195.

96 S. Jenkins, 'Ressentiment, Imaginary Revenge, and the Slave Revolt', pp. 196-7

97 V. Armstrong, "Our Mãori Connection: The impact of colonisation on one Southland whānau (Masters thesis), Auckland University of Technology, 2016, p. 8.

98 S. Jenkins, 'Ressentiment, Imaginary Revenge, and the Slave Revolt', p. 197.

99 F. Nietzsche, On the Genealogy of Morals, p. 14.

100 L. Pihama, 'Moko Kauae: A Māori Women's Right, 23 May 2018, in https://leoniepihama.wordpress.com/2018/05/23/moko-kauaea-maori-womens-right/

101 D. J. Bem, 'Self Perception: An Alternative Interpretation of Cognitive Dissonance Phenomena', in Psychological Review, vol. 74, no. 3, 1967, p. 184; A. J. Elliot and P. G. Devine, 'On the motivational nature of cognitive dissonance: Dissonance as psychological discomfort', in Journal of Personality and Social Psychology, vol. 67, no. 3, 1994, p. 383.

102 B. Reginster, 'Nietzsche on Ressentiment and Values', p. 283.

103 G. Smith, T. Hoskins \& A. Jones, 'Interview: Kaupapa Maori: The dangers of domestication', in New Zealand Journal of Educational Studies, vol. 47, no. 2, 2012, p. 12. 